\title{
Student Satisfaction with a Web-Based Dissertation Course: Findings from an International Distance Learning Master's Programme in Public Health
}

Roger Harrison, Isla Gemmell, and Katie Reed

University of Manchester, England

\section{Abstract}

\section{Introduction}

Online distance learning (e-learning) is now an established method for providing higher education, in the UK and across the world. The focus has largely been on developing the technology, and less attention has been given to developing evidence-informed course provision. Thus the effectiveness of this teaching approach, and its acceptability to students, is, at times, uncertain. Many higher education courses require students to submit a dissertation. Traditional face-to-face courses will include meetings between the student and an allocated supervisor, to support the dissertation component of the course. Research into the supervisory relationship and student satisfaction has focused on doctoral students. Little is known about the experiences of students studying for a master's degree.

The aim of the current study was to measure student satisfaction with the dissertation course as part of a fully online distance learning master's programme in public health.

\section{Methods}

All students submitting a dissertation as part of their master's programme in Public Health were sent an electronic survey to complete, in September 2012. The 34 item questionnaire used a four point Likert scale for students to rate levels of satisfaction across key components of the course, including preparatory materials, study skills, and support, and with the amount and content of supervision. Open ended/free text questions were used to determine factors associated with levels of satisfaction and to 
gain student feedback on the course overall. The constant comparative method was used to identify key themes from the free-text responses.

\section{Results}

Of the 45 students submitting a dissertation, 82\% (37) responded to the survey. The majority of students, $85 \%$ (28) were satisfied or very satisfied with the dissertation course overall. Levels of satisfaction remained high for many of the components examined. Differences were observed for part time and full time students, and for the type of dissertation, but these were not significant. Similarly, non significant findings were observed for associations between satisfaction and the estimated number of contacts initiated with their supervisor, and for the time spent working on their dissertation. The constant comparative analysis identified key themes and feedback included 'self development', 'peer support', and 'writing skills'.

\section{Conclusions}

Generally high levels of satisfaction were received from students studying a dissertation course as part of a fully online distance learning programme in public health. Areas for further improvement were identified and the results act as a benchmark for future quality enhancement. These findings suggest that appropriate information, study skills, and supervisory support can be provided in an online distance learning programme, for students taking a master's level dissertation course.

Keywords: Supervision; dissertations; thesis; master's degree; postgraduate; satisfaction

\section{Introduction}

E-learning refers to learning facilitated and supported through the use of information and communications technology' (J ISC, 2007). This includes complete distance learning through to its inclusion in face-to-face/ classroom teaching (blended or hybrid learning). The internet is now a central teaching platform, with over a quarter of students in higher education registered on an e-learning course in America (Allen \& Seaman, 2013). In England, senior politicians described e-learning as an 'historic opportunity' for students and educators (Coughlan, 2013), as societies become more 'digitised' (Weller, 2011).

This paper is focused on distance learning programmes provided over the internet. These ' $e$--learning courses offer a number of possible advantages to students, including flexibility regarding their location of study, choice when they engage with the course materials, and more control over their individual pace of learning (Childs, Blenkinsopp, Hall, \& Walton, 2005). Students with an internet connection, regardless of their location in the world, can register for e-distance learning courses. Evidence reviews find 
that e-learning can be as effective and at times more effective than face-to-face teaching in higher education (Cook, Levinson, \& Garside, 2008; Means, Toyama, Murphy, Bakia, $\&$ J ones, 2009). It is a preferred choice for many groups of students (Halsne \& Gatta, 2002) and can result in similar levels of student satisfaction when compared with faceto-face approaches (Allen, Bourhis, \& Burrell, 2010; Driscoll, J icha, Hunt, Tichavsky, \& Thompson, 2012). Consequently, e-distance learning courses have the potential to provide access to effective higher education for hundreds of thousands of students who had previously been disadvantaged by their geographical location (Naidoo, 2005) and the challenge of studying whilst working (Collis \&Wende van der, 2002).

Our previous research has shown that diversity in the student population can enrich the experience of individual students on an e-distance learning programme (Gemmell, Harrison, Clegg, \& Reed, 2014). The current study examines student satisfaction with the dissertation course as part of an e-distance learning master's programme in public health. Student satisfaction is an important quality indicator of any course and regarded as one of 'five pillars' of quality in e-learning, alongside learning effectiveness, access, faculty satisfaction, and institutional cost effectiveness (The Sloan Consortium, 2013). In the UK, the National Student Survey includes measures of student satisfaction, amongst other things "to contribute to public accountability and help inform the choices of prospective students" (HEFCE, 2012). As part of their marketing strategy, course providers will wish to show high levels of student satisfaction in these publically available league tables. With a rise in student fees and expectations, this type of information will no-doubt be a key component of a student's decision to register for a particular course.

Student satisfaction with an e-learning course is influential in their learning journey. It has been shown to have a positive effect on motivation and engagement with the course materials, and is linked with overall course performance (Sahin \& Shelley, 2008; Wickersham \& McGee, 2008). Students found to be dissatisfied with a course are more likely to end their studies early (Levy, 2007). Given the centrality of student satisfaction to students and course providers, it is ironic that "in general [there is] a scarcity of studies of the learner experience" to inform the development and delivery of future elearning courses (Sharpe \& Benfield, 2005). Key factors known to influence student satisfaction on e-learning courses include the relevance of the course materials, the learner's autonomy, and their competence with technology (Ke \& Kwak, 2013) (Bolliger \&Halupa, 2012; Carroll, Booth, \& Papaioannou, 2011).

Postgraduate courses often include a research or project based dissertation, and students are allocated an academic supervisor to support this process (Meeus *, Van Looy, \& Libotton, 2004). The supervisor-student relationship is another important factor in the students' performance and their levels of satisfaction (de Kleijn, Mainhard, Meijer, Pilot, \& Brekelmans, 2012). Attention on this topic has usually focused on the dissertation for postgraduate research students (PhD). This overlooks the needs of masters students, despite their greater number (Anderson, Day, \& McLaughlin, 2008). Furthermore, few have attempted to evaluate the quality of the entire dissertation 
process (Aspland, Edwards, O'Leary, \& Ryan, 1999), and move beyond the influence of the supervisor to examine the provision and access to resources and other institutional factors (Buttery \& Ruchter, 2005). Finally, we found no studies examining student satisfaction with their dissertation unit as part of an e-distance learning programme. This gap needs to be reduced if we are to use evidence informed approaches to increase the quality of future courses whilst enhancing the student experience.

The aim of the study was to assess student satisfaction with key elements of a dissertation course, including but not limited to supervision, as part of a master's in public health (MPH). The MPH was established in 2001 by the University of Manchester, England (www.manchester.ac.uk/ mph) and it is a fully online e-distance learning programme. Each year, the course accepts up to 100 new students onto the full or part time programme, of whom usually two thirds reside in the UK and Europe, and a third in the rest of the world. The course is delivered completely over the internet using the virtual learning environment Blackboard 9 (www.blackboard.com).

For the MPH, the dissertation course is the final part of the master's programme. Students register for the dissertation course after passing three core units (Evidence Based Practice, Fundamentals of Epidemiology, and Biostatistics) and five optional units, selected from 16 available units covering a range of public health themes. Each unit is worth 15 credits and based on 150 hours study time per unit. The dissertation is worth 60 credits and needs to be within a word length of 8,000 to 10,000 words. Students have up to 12 months to complete and submit the final dissertation. Unlike more traditional postgraduate courses, on the MPH students do not carry out primary research. Instead, they select from one of five different models, designed to reflect the diversity of public health learning needs requirements. These are (1) a research grant proposal, (2) an adapted quantitative or qualitative systematic review, (3) an analysis of existing data sets, (4) a public health/outbreak report, or (5) a qualitative theoretical study. After registering for the dissertation unit, students have up to 12 months in which to submit their thesis.

The wide range of resources available to all students are designed to help prepare them for the dissertation unit and to provide further support and direction over the 12-month writing period. Giving access to the resources as soon as students register for the MPH gives an opportunity for students to familiarise themselves with the material and to help them think about ideas for their dissertation earlier in the course.

The dissertation handbook is a central point for information on the dissertation process and administrative procedures. It includes a section on "What is the role of a supervisor?" and "What students can realistically expect". There is a self-directed learning unit which covers the following key topics: "What is a dissertation?"; "How to select and write a suitable proposal"; "How to write a critical literature review"; and "How to present your work". This includes structured learning materials and a range of resources including short video presentations from dissertation tutors and PowerPoint 
presentations. Other resources include online access to copies of previous dissertations that were awarded a distinction and links to writing and study guides.

Students are encouraged to develop their own ideas for their dissertation. Many use work-based experiences and/or career aspirations to form the basis for their dissertation. Students submit a dissertation proposal using a structured application form to frame their ideas and methodology. They then receive written feedback from three dissertation tutors. This process is intended to ensure that the student's ideas have the potential to meet the requirements for the dissertation, within the time permitted and the resources available to the student. Once students have a satisfactory proposal for their dissertation, they are put in touch with a supervisor to support the remainder of their work. Most supervisors are based within the University of Manchester. Senior academics are self-selected for this role, to match them with the student's dissertation topic and the selected dissertation model. All supervisors are invited to training sessions and/or are sent written guidance. They also have access to the same learning and support materials as the student. Supervisors can seek additional support at an individual level from the course dissertation lead (RAH). As a guide, supervisors are expected to provide around 16-20 hours of supervisory support in total, over the academic year. This includes responding to student queries, giving feedback on their written work, and providing general guidance, information, and support. In the initial stage, supervisors are encouraged to provide an introductory email to their student, and to agree mutually acceptable methods for communication (e.g., email, telephone, Skype, Google $\mathrm{e}^{+}$. Similarly, in the initial stages, students are encouraged to introduce themselves to their supervisor and to identify any immediate or potential future learning needs. The whole process is monitored by the course dissertation lead (RAH), who can also respond to individual queries and further support needs from students and their supervisor.

\section{Methods}

In September 2012, all students submitting their dissertation were invited to complete an online satisfaction survey which was sent to their university email address. The survey was produced and distributed using SelectSurvey.net version 4.07. The invitation email provided an overview of the survey with a clear statement that it was anonymous. A reminder was sent two weeks later, and two weeks after that the survey was closed. The survey was distributed after students had submitted their dissertation but before they received their marks.

The 34 item questionnaire sought levels of satisfaction with the themes: (1) preparatory information, (2) study skills resources, and (3) supervision. Information was also collected on registration status (full or part time) and the type of dissertation model selected by the student. It was not possible to collect more detailed information on baseline characteristics as this could have broken the student's anonymity. 
The majority of questions used a four-point Likert scale. The analysis calculated frequencies and percentages for questions using the Likert scale. Fishers exact test was used to test for associations between levels of satisfaction and registration status, type of dissertation model, and level of contact with supervisor. Open ended/ free text questions were used to obtain information on a number of themes. These were analysed using the constant comparative method (Maykut \& Morehouse, 1994). Students were asked to estimate the amount of time they spent working on their dissertation overall, in numbers of hours which were then rounded up or down to the nearest whole number. This variable was not normally distributed and the Kruskal Wallis test was used to test for an association between overall satisfaction and the median time spent working on the dissertation. The study was conducted as part of a service evaluation. Ethical approval and participant signed consent was not required. Students could opt out by not completing the survey without giving any reason.

\section{Results}

In September 2012, 45 students were expected to submit a completed dissertation and they were all sent a copy of the online survey. The number of students responding to the survey was 37 (82\%). The majority of respondents, 33 (89\%) were part time students, compared with 4 (11\%) doing the course full time. This compares with 38 (84\%) part time and 7 (16\%) full time students taking the dissertation that year. For reasons unknown, three students only answered the first four questions, leaving 34 students who completed the full survey.

Most dissertation students had selected the option of a systematic review (41\%) and only one student responding to the survey had submitted a dissertation based on a qualitative/ theoretical study (Table 1).

Table 1

Baseline Characteristics of Survey Respondents Compared with all Students Eligible for the Survey

\begin{tabular}{|c|l|l|}
\hline & $\begin{array}{l}\text { Everyone } \\
\text { sent the } \\
\text { survey }\end{array}$ & $\begin{array}{l}\text { Survey } \\
\text { respondents }\end{array}$ \\
\hline Dissertation option: & $\mathrm{N}(\%)$ & $\mathrm{n}(\%)$ \\
\hline Systematic review & $19(42)$ & $15(41)$ \\
\hline Public health / outbreak report & $11(24)$ & $12(31)$ \\
\hline Analysis of existing data set & $9(20)$ & $5(14)$ \\
\hline Research grant proposal & $3(7)$ & $4(11)$ \\
\hline Qualitative/ theoretical study & $3(7)$ & $1(3)$ \\
\hline Total & $45(100)$ & $37(100)$ \\
\hline
\end{tabular}




\section{Overall Satisfaction}

Students were asked "overall, how would you rate your experience of the dissertation unit?" Of those responding, 85\% (28) replied that they had had a very positive or positive experience overall. Only 15\% (5) of students said that their experience was not so good. Students experience was observed to vary between part time and full time students, with only part time students expressing a less than positive experience (Table 2). These differences were not statistically significant (Fishers exact test $=0.830, p=$ 1.000).

Table 2

Level of Satisfaction Overall Based on Type of Registration

\begin{tabular}{|l|l|l|l|}
\hline & $\begin{array}{l}\text { Part-time } \\
\mathrm{n}(\%)\end{array}$ & $\begin{array}{l}\text { Full-time } \\
\mathrm{n}(\%)\end{array}$ & $\begin{array}{l}\text { All } \\
\mathrm{n}(\%)\end{array}$ \\
\hline Very positive & $6(20)$ & $1(33)$ & $7(21)$ \\
\hline Positive & $19(63)$ & $2(67)$ & $21(64)$ \\
\hline Not so good & $5(17)$ & $0(0)$ & $5(15)$ \\
\hline Not good at all & 0 & 0 & 0 \\
\hline Total & $30(100)$ & $3(100)$ & $33(100)$ \\
\hline
\end{tabular}

There was some variation in the levels of satisfaction with the course overall by the type of dissertation model students had chosen to do (Table 3). Most students expressed at least a positive experience. However, these findings are difficult to interpret because of the small number of students within each category and percentages have not been presented.

Table 3

Level of Satisfaction Overall by Type of Dissertation Model

\begin{tabular}{|l|l|l|l|l|l|}
\hline & $\begin{array}{l}\text { Research } \\
\text { grant } \\
\text { proposal }\end{array}$ & $\begin{array}{l}\text { Systematic } \\
\text { review }\end{array}$ & $\begin{array}{l}\text { Analysis of } \\
\text { existing } \\
\text { data }\end{array}$ & $\begin{array}{l}\text { Public } \\
\text { health } \\
\text { report }\end{array}$ & $\begin{array}{l}\text { Qualitative/ } \\
\text { theoretical } \\
\text { study }\end{array}$ \\
\hline Very positive & & 4 & & 1 & \\
\hline Positive & 3 & 7 & 4 & 6 & 1 \\
\hline $\begin{array}{l}\text { Not so } \\
\text { positive }\end{array}$ & 1 & 4 & 1 & 0 & \\
\hline $\begin{array}{l}\text { Not positive } \\
\text { at all }\end{array}$ & 0 & 0 & 0 & 0 & 0 \\
\hline Total & 4 & 15 & 6 & 7 & 1 \\
\hline
\end{tabular}

(1 non-responder) (Fishers exact test $=4.264, \mathrm{p}=0.380$ ).

Note. In the statistical analysis the categories where combined to public health report, systematic review, or other because of small numbers in some cells. 
The 'free-text' question asked students 'What key issues/experiences influenced your answer to this question?". The constant comparative analysis identified two main themes from their responses to this question, 'preparedness' and 'self development'.

\section{Preparedness.}

Students felt that they had been adequately prepared to start work on their dissertation. They valued an opportunity to select a topic/question related to their current employment and/or particular interests. Students appreciated the amount of information available about the different aspects of the dissertation process. Generally, this was easy to access, and any questions sent to members of staff, including the administrative team, were quickly answered. Some were disappointed that the supervisor was not allocated until their dissertation proposal had been accepted and had wanted "discussion with experienced supervisors for how to go about choosing a dissertation topic right at the beginning of the dissertation" [respondent 27].

\section{Self-development.}

Some students used the question as an opportunity to reflect on their own learning and self-development gained whilst taking the dissertation unit. One noted their achievement in producing a dissertation, and another had gained confidence in understanding what they had learnt. One student described the dissertation unit as "a voyage of self-discovery" [respondent 25]. Whilst writing a dissertation was challenging, they had adequate support. One student commented, "had to do my own readings and research to do the [systematic] review" [respondent 16], suggesting that this had been unexpected. One felt that "for someone who is not research minded like me, it will always remain a necessary evil" [respondent 5], whilst another reflected on relief with "the fact that it is over now" [respondent 6].

\section{Satisfaction with Preparatory Information}

Five questions sought information about student satisfaction with the preparatory information about the dissertation unit. At least 71\% (24) of students were satisfied or very satisfied with each of these five areas (Table 4). A small number of students expressed some level of dissatisfaction with one or more items relating to the preparatory information. 
Table 4

Levels of Satisfaction with Preparatory Information

\begin{tabular}{|l|l|l|l|l|}
\hline & $\begin{array}{l}\text { Very } \\
\text { satisfied }\end{array}$ & Satisfied & $\begin{array}{l}\text { Not very } \\
\text { satisfied }\end{array}$ & $\begin{array}{l}\text { Not } \\
\text { satisfied at } \\
\text { all }\end{array}$ \\
\hline & $\mathrm{n}(\%)$ & $\mathrm{n}(\%)$ & $\mathrm{n}(\%)$ & $\mathrm{n}(\%)$ \\
\hline $\begin{array}{l}\text { Provision of information about } \\
\text { starting the dissertation }\end{array}$ & $10(29)$ & $24(71)$ & 0 & 0 \\
\hline $\begin{array}{l}\text { Content of the dissertation } \\
\text { handbook }\end{array}$ & $9(26)$ & $24(71)$ & $1(3)$ & 0 \\
\hline $\begin{array}{l}\text { Presentation of the dissertation } \\
\text { handbook }\end{array}$ & $6(18)$ & $27(79)$ & 0 & $1(3)$ \\
\hline $\begin{array}{l}\text { Guidance on the marking and } \\
\text { grading scheme for the completed } \\
\text { dissertation }\end{array}$ & $6(18)$ & $25(74)$ & $3(9)$ & 0 \\
\hline $\begin{array}{l}\text { Guidance on completing the } \\
\text { dissertation proposal form. }\end{array}$ & $3(9)$ & $\begin{array}{l}28 \\
(82 \%)\end{array}$ & $3(9)$ & 0 \\
\hline
\end{tabular}

Students where then asked to comment on "how could we improve information for students about the dissertation unit?". The constant comparative analysis identified four main themes, 'developing the dissertation proposal', 'time planning', 'peer support', and location of information'.

\section{Developing the dissertation proposal.}

A number of students wanted to have been given more information and support to develop the initial dissertation proposal. This included a "live chat forum" [respondent 27] to discuss their ideas with a tutor during office hours and more examples of previous dissertations which included the marker's critique. Another suggested "more video content on how to go about doing the dissertation, to choose the topic and type of work, emphasise the number of hours needed to complete..." [respondent 28].

\section{Time planning.}

A range of ideas were put forward by students to help increase future satisfaction with support for keeping on track towards the submission date. This included sending a timeline of key dates and stages for the dissertation unit to all students at an early stage. Others suggested an email to "prompt what stage students should be at with their dissertation" [respondent 24].

\section{Peer support.}

One student thought that it would have helped to have seen "hints and tips" [respondent 7] from previous students who had completed the dissertation unit. Another thought it would be a good idea to regularly summarize individual questions 
from students and produce a live' updated Frequently Asked Questions [respondent 14] section as an addendum to the handbook.

\section{Location of information.}

Several students had found difficulties in accessing information, and that whilst the "information was adequate....I did find that it was not always to be found in the place I expected" [respondent 13]. One solution offered was to put everything into the dissertation handbook rather than having it in different places within the dissertation unit in Blackboard.

\section{Satisfaction with Study Skills and Resources}

Eight questions sought information on levels of satisfaction with the general study skills and resources section of the dissertation unit. The majority of students were satisfied or very satisfied with guidance on completing the dissertation proposal form (91\%), the content in the self-directed teaching unit (91\%), and the amount of general information on writing a dissertation (86\%). But at least $26 \%$ (9) were less than satisfied with four of the other seven items examining this area (Table 5).

Table 5

Satisfaction with Guidance on Selecting and Writing the Dissertation

\begin{tabular}{|l|l|l|l|l|}
\hline & $\begin{array}{l}\text { Very } \\
\text { satisfied }\end{array}$ & Satisfied & $\begin{array}{l}\text { Not very } \\
\text { satisfied }\end{array}$ & $\begin{array}{l}\text { Not } \\
\text { satisfied at } \\
\text { all }\end{array}$ \\
\hline & $\mathrm{n}(\%)$ & $\mathrm{n}(\%)$ & $\mathrm{n}(\%)$ & $\mathrm{n}(\%)$ \\
\hline $\begin{array}{l}\text { Guidance on complete the } \\
\text { dissertation proposal form }\end{array}$ & $3(9)$ & $28(82)$ & $3(9)$ & 0 \\
\hline $\begin{array}{l}\text { Amount of guidance given to } \\
\text { choosing a dissertation topic }\end{array}$ & $3(9)$ & $22(65)$ & $8(24)$ & $1(3)$ \\
\hline $\begin{array}{l}\text { Amount of general information on } \\
\text { writing a dissertation }\end{array}$ & $4(12)$ & $25(74)$ & $4(12)$ & $1(3)$ \\
\hline $\begin{array}{l}\text { Relevance of the material to your } \\
\text { chosen dissertation topic }\end{array}$ & $4(12)$ & $21(62)$ & $8(24)$ & $1(3)$ \\
\hline $\begin{array}{l}\text { Amount of guidance on } \\
\text { developing and planning your } \\
\text { dissertation }\end{array}$ & $4(12)$ & $21(62)$ & $8(24)$ & $1(3)$ \\
\hline $\begin{array}{l}\text { Suggestions for background } \\
\text { reading }\end{array}$ & $2(6)$ & $23(68)$ & $8(24)$ & $1(3)$ \\
\hline $\begin{array}{l}\text { Suggestions for sources for } \\
\text { further support }\end{array}$ & $3(9)$ & $22(65)$ & $9(26)$ & 0 \\
\hline $\begin{array}{l}\text { Content covered in the self- } \\
\text { directed teaching unit }\end{array}$ & $4(12)$ & $27(79 \%)$ & $3(9 \%)$ & 0 \\
\hline
\end{tabular}


Students were asked "overall, how could we improve information covered in the blackboard dissertation skills unit?". Two main themes were identified in the analysis, 'writing and structure' and 'assessment'.

\section{Writing and structure.}

Students said that they would have liked more guidance and information on how to write and structure a dissertation: "the dissertation course had several good ideas and provided guidance but for students who had never written a dissertation, more help on the actual writing process would have been helpful" [respondent 33]. Some students came up with helpful suggestions including a video from the tutor and from past students, to talk about some of the more practical aspects of writing a dissertation: "even a video of a past student(s) indicating what they did and what they would do differently" [respondent 9] and "it would have been helpful to learn different practical approaches that work well for others such as outlining the chapters and then starting a file for each chapter" [respondent 34].

\section{Assessment.}

An interesting comment made by one student reflected that the students' use of the dissertation materials was not formally assessed. They suggested that it would complement the material in the core taught unit Evidence Based Practice: "the idea is not only use EBP learning in the dissertation but think in the dissertation while learning EBP" [respondent 17]. Thus dissertation skills could form part of the assessment in the core unit Evidence Based Practice.

\section{Supervision}

The median number of hours estimated by students to have spent working on their dissertation was 250 (range 40-2,000). (Figure 1) 


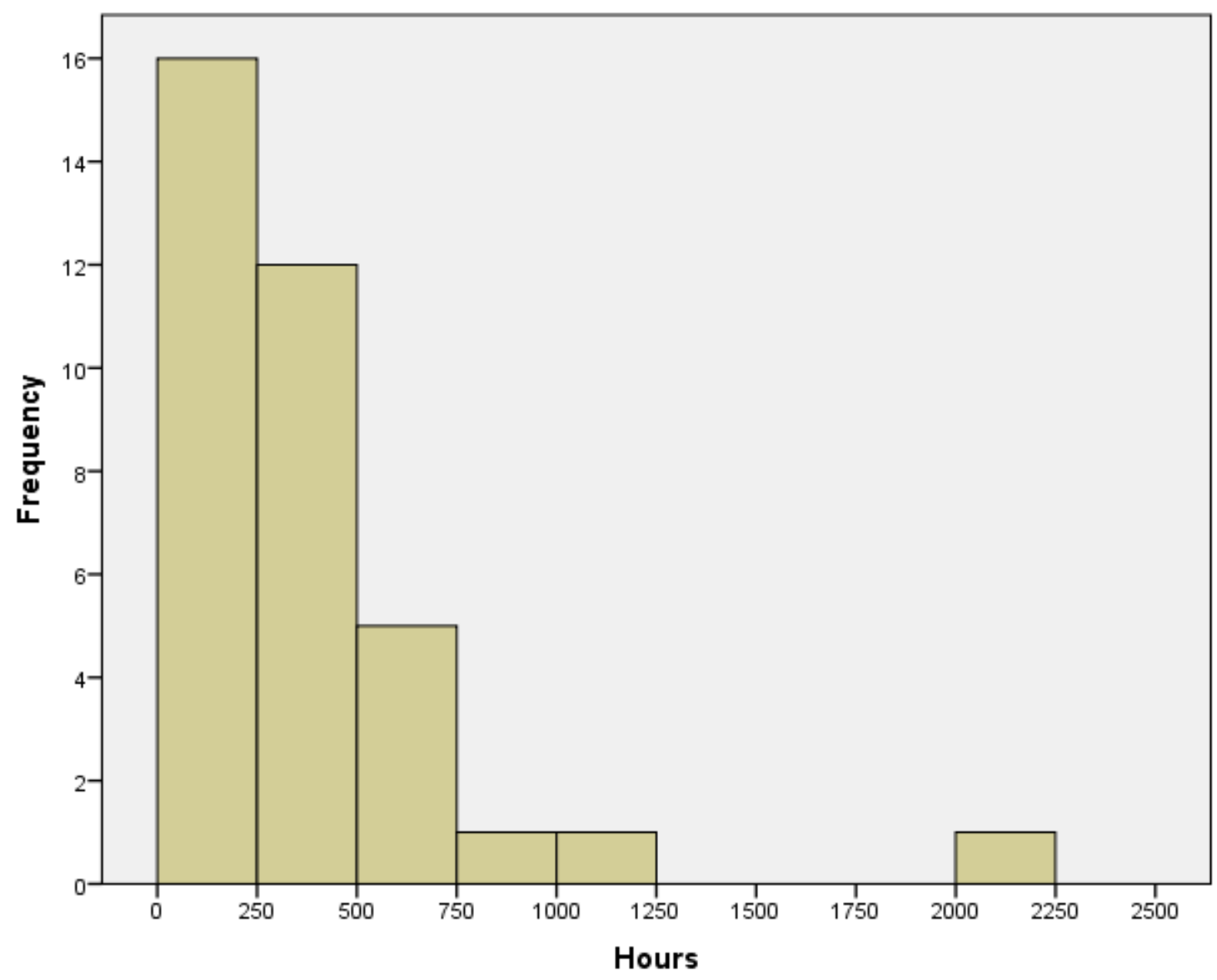

Figure 1. Student estimated time (hours) spent working on their dissertation.

Students were asked to estimate how often they initiated contact with their supervisor, with the options of once a week, once a month, every three months, or less than once every three months. Just over half the students, 19 (56\%), stated that they initiated contact with their supervisor at least once a month, 9 (26\%) about once every three months, and 5 (15\%) less than three times over the dissertation year. One student initiated contact with the supervisor on a weekly basis. There was some variation in the level of satisfaction with the course overall and the amount of time students contacted their supervisor (Table 6). The results suggest that students who initiated contact at least once a month were more likely to have had a positive experience of the course. However these findings were not statistically significant (Fishers exact test $=2.423, \mathrm{p}=$ 0.694 ). 
Table 6

Overall Satisfaction with the Course and Estimated Frequency of Contact with their Supervisor

\begin{tabular}{|l|l|l|l|l|}
\hline & \multicolumn{4}{|l|}{$\begin{array}{l}\text { Estimated frequency that the students initiated contact with their } \\
\text { supervisor }\end{array}$} \\
\hline $\begin{array}{l}\text { Satisfaction } \\
\text { level }\end{array}$ & $\begin{array}{l}\text { Once a week } \\
\mathrm{n}(\%)\end{array}$ & $\begin{array}{l}\text { At least once } \\
\text { a month } \\
\mathrm{n}(\%)\end{array}$ & $\begin{array}{l}\text { About once } \\
\text { every 3 } \\
\text { months } \\
\mathrm{n}(\%)\end{array}$ & $\begin{array}{l}\text { Less than once } \\
\text { every 3 months } \\
\mathrm{n}(\%)\end{array}$ \\
\hline Very positive & $1(100)$ & $5(26)$ & $2(22)$ & $0(0)$ \\
\hline Positive & 0 & $12(63)$ & $5(56)$ & $4(80)$ \\
\hline $\begin{array}{l}\text { Not so } \\
\text { positive }\end{array}$ & 0 & $2(11)$ & $2(22)$ & $1(20)$ \\
\hline $\begin{array}{l}\text { Not positive } \\
\text { at all }\end{array}$ & 0 & 0 & 0 & 0 \\
\hline Total & $1(100)$ & $19(100)$ & $9(100)$ & $5(100)$ \\
\hline
\end{tabular}

Five questions were used to assess student satisfaction with the potential for and the actual supervision they received. The dissertation handbook outlined that students could expect around 16 hours of support from their supervisor over the academic year, and that they should allow up to 10 working days to receive feedback on written work. At least $85 \%$ of students were 'satisfied' or 'very satisfied' across these areas (Table 7). As many as $15 \%$ (5) of students expressed some level of dissatisfaction with the amount of supervision they received, the amount of feedback given, and the extent they felt their supervisor supported them.

Table 7

Satisfaction with Potential and Actual Supervision Received

\begin{tabular}{|l|l|l|l|l|}
\hline & $\begin{array}{l}\text { Very } \\
\text { satisfied }\end{array}$ & Satisfied & $\begin{array}{l}\text { Not very } \\
\text { satisfied }\end{array}$ & $\begin{array}{l}\text { Not } \\
\text { satisfied at } \\
\text { all }\end{array}$ \\
\hline & $\mathrm{n}(\%)$ & $\mathrm{n}(\%)$ & $\mathrm{n}(\%)$ & $\mathrm{n}(\%)$ \\
\hline Potential provision for supervision & $14(42)$ & $17(52)$ & $2(6)$ & 0 \\
\hline $\begin{array}{l}\text { Amount of supervision actually } \\
\text { received }\end{array}$ & $14(42)$ & $14(42)$ & $3(9)$ & $2(6)$ \\
\hline $\begin{array}{l}\text { Time it took your supervisor to } \\
\text { respond to queries/ questions }\end{array}$ & $17(52)$ & $12(36)$ & $4(12)$ & 0 \\
\hline Amount of feedback on your work & $17(52)$ & $11(33)$ & $4(12)$ & $1(3)$ \\
\hline $\begin{array}{l}\text { The extent that your supervisor } \\
\text { supported you over the academic } \\
\text { year }\end{array}$ & $16(48)$ & $12(36)$ & $3(9)$ & $2(6)$ \\
\hline
\end{tabular}

(One student did not answer these questions; $\mathrm{n}=33$ ) 
Three main themes were identified when students were asked "how supervision could be improved". These were 'methods of communication', how to use a supervisor', and 'availability'.

\section{Methods of communication.}

Supervision online provides a number of different ways in which students can contact their supervisor. Students commented that this was usually done by email, but making a compulsory initial Skype or telephone call with the supervisor would be helpful, as "that way, the relationship will kick off immediately without delay" [respondent 8]. One student suggested that this needed to continue as supervisors "did not have any dedicated time over the phone to talk through issues, just quick emails or ad hoc phone calls" [respondent 26].

\section{How to use a supervisor.}

Students made a few comments relating to the process of working with a supervisor. Several students identified a need for them to be encouraged to make contact with their supervisor initially, and then during the supervisory period and that "I imagine this is a common issue for some students" [respondent 11]. The idea of using a survey part way through the course was seen by one student as another way of encouraging student to supervisor contact. One commented that "the dissertation process is difficult, and supervisors can be over-critical sometimes even contradicting earlier directives given, which can be frustrating" [respondent 5].

\section{Availability.}

Some students were clearly frustrated at the apparent lack of availability of their supervisor, and sometimes there were "long gaps in communication such as my supervisor being away for extended periods of time that I was not aware of" [respondent 15]. Another commented that "I was provided with a supervisor who was not available during the final months of writing my dissertation, which was when most of my work was to be done" [respondent 32] and "I was somewhat surprised that my supervisor was on holiday in the time leading up to the deadline for the dissertation" [respondent 13].

Despite the variation in levels of satisfaction, and the comments raised above, many students commented positively on the quality of the dissertation unit. Many comments reflected the following sentiments: "Overall you are doing well" [respondent 26] and "I actually think that it is at a very high level already" [respondent 3]. Several students praised their own supervisor, with "the supervision I got from XXXXXX was excellent in every sense.....she epitomised a good supervisor in every sense" [respondent 2] or "XXXX was excellent, supportive and flexible..... I could not have asked for better supervision" [respondent 4], and "it was like no other I have gotten in previous studies" [respondent 2]. 


\section{Discussion}

We gained considerable insight into the experience of students taking a dissertation unit on an e-distance learning master's course in public health. It was encouraging to find that the majority of students were satisfied or very satisfied with the course unit overall, and with particular dimensions that we assessed. Our findings show that students were well-informed about the dissertation process, had access to usable, relevant information, and received good levels of supervisory support. We did expect to see some variation in levels of satisfaction for the different items assessed because of different academic and professional experiences at the start of the course. Moreover, their reasons for registering on the e-distance learning master's degree (Chen, Lambert, \& Guidry, 2010) and their use of e-learning technology varied widely and this may have influenced their general satisfaction. The student feedback confirms how we largely accommodated these varied needs to the satisfaction of the student. Previous authors have described the master's dissertation as "an elusive chameleon" and a source of confusion and student dissatisfaction (Pilcher, 2011). However, our evidence suggests that providing student-orientated resources and support, informed with relevant pedagogical evidence, can provide clarity and transparency to the requirements of the final product.

A dissertation is a requirement of many post graduate courses. Yet there is surprisingly little published evidence about the student experience of this important aspect of the course. Even fewer studies have reported levels of student satisfaction with their dissertation unit on an e-learning course. As such, the current study helps to plug an important research gap. Our findings are at least comparable to levels of overall satisfaction reported in the UK National Student Survey, with an average of $85 \%$ of students satisfied with the quality of a course (HEFCE, 2012). Whilst this national survey of higher education includes face-to-face and online learning courses, it acts as a benchmark for students' experiences with the MPH.

A strength of our study is the combination of fixed question responses and open-ended questions. The latter provided further insight into student satisfaction and factors influencing this. The good response rate increased the generalizability to students enrolled on this course. Students did not always report equal levels of satisfaction for each of the items considered. This heterogeneity suggests that students were reflecting on their experience specific to each question item, rather than applying a generic response to hasten completion of the survey, thus indicating good validity of the survey methods. We acknowledge that our findings are based on a single academic year and the sample size might have been underpowered to identify statistically significant relationships in the analyses carried out.

We were unable to identify an existing validated satisfaction survey that was applicable to an e-distance learning course in an international context. Where possible, we used previously published studies to inform the dimensions assessed and the construction of the questions (Arambewela \& Hall, 2009). Moreover, we couldn't explore predictors of 
satisfaction including gender, age, and previous educational attainment, as this would have reduced the likelihood of maintaining student anonymity. Similarly we had no information on previous use of e-learning and confidence with technology .

The survey highlights the need to provide better personal communication with our students before and after their dissertation proposal has been approved. In the current system, students are not allocated a supervisor until their proposal has been approved. Thus, whilst having access to the learning resources, they are expected to develop their own ideas into a workable proposal before they receive support from a supervisor. Public health covers a very wide breadth of topics making it difficult to identify a suitable supervisor until the student's dissertation topic is known. Moreover, public health professionals need to be able to develop independent skills in evidence based practice, which includes identifying, framing, and answering a particular question and then making sense of the information. Thus the current process acts as a gateway to the more independent component of the dissertation course. In addition to the dissertation skills unit and other resources, students can use the discussion board in Blackboard to raise ideas and queries about their dissertation, and to receive feedback from other students, respond to other students, and with further postings from the dissertation tutor (RAH). Discussion boards have been found to be a valuable tool to support students in healthcare environments (Thomas, 2013). Despite the reasons for our current process, we do need to consider how we can be more proactive during the preliminary stages, given the feedback presented in this survey.

Having been allocated a supervisor, a number of students went on to report dissatisfaction with the amount, timing, and purpose of the supervisor-student contact. As one might expect, this interaction is a key factor effecting student satisfaction (Kuo, Walker, Belland, \& Schroder, 2013). Our study suggests that some supervisors need to be more proactive in communicating with their supervisees, and to provide better timely and constructive support. This includes providing students with relevant educational 'scaffolding' that encourages them to reflect on their ideas and to use this as part of the learning process (Quan-Baffour \& Vambe, 2008). Supervisors also need to be encouraged to use their own and other real life examples, to support the students' understanding and self-reflection (Sahin \& Shelley, 2008).

The feedback from students in the current survey lends support to continued training for new and existing supervisors. This needs to remain responsive to the needs of our dissertation students and to reflect any changes in the course delivery and available use of technology (McCallin \& Nayar, 2012). We are well aware of the rapidly developing technology to deliver and support e-learning programmes. At times, this challenges existing teaching methods and raises new pedagogical approaches compared with oncampus supervision (Abrami, et al, 2012). A particularly attractive development following Web 2.0 technology is the ease at which social learning communities can be created. These can provide a virtual space for supervisors and their students, and/ or be restricted to their peers to interact in various ways (Batalla-Busquets \& Pacheco-Bernal, 2013; Bennett, Bishop, Dalgarno, Waycott, \& Kennedy, 2012). A systematic review 
found that communication was a key theme in the literature exploring e-learning for adult learners who work (Carroll et al., 2011). The authors of the review suggested that this social learning interaction is perhaps more influential amongst working adults in higher education, as students are likely to have shared professional beliefs and experiences, enhancing their potential to learn from each other (Carroll et al., 2011). However, as with all new technologies, we need to ensure that an approach like this would increase student satisfaction, amongst other things, which is currently uncertain (Kuo et al., 2013) . Similarly, we would need to consider the role (or not) of supervisors in social learning communities (Zhang, Perris, \&Yeung, 2005).

Sceptics of e-distance learning courses may use any accounts of student dissatisfaction to add to their concerns about this learning method. Even advocates of e-learning recognise that "students miss those serendipitous moments of learning that so often occur in a F2F [face-to-face] environment-the overheard remark, the discussion in the hallway, the before-class updates" (Sanders, 2006). Few would doubt the potential value of these interactions. Yet higher levels of interaction can occur between student and tutor in an e-learning environment compared with face-to-face courses (Swan, 2006). Of particular value to working adults enrolled on an e-distance learning programme is that these communications do not need to be in 'real time', enabling students to effectively communicate with peers and supervisors at their convenience (Abrami et al., 2012). Furthermore, communicating with students using email means that they can refer back to communications with their supervisor, which is a potential advantage over face-to-face interactions with a supervisor.

\section{Conclusion}

Our findings support the view that a master's level dissertation unit on an e-distance learning programme can achieve high levels of student satisfaction. These findings are important given the lack of existing evidence on this particular topic, despite the established requirement for a dissertation on master's programmes, and the now established use of e-distance learning programmes. Our findings highlight the need to provide the right environment for effective student-supervisor communication and to further develop appropriate social learning communities to support dissertation students. 


\section{References}

Abrami, P. C., Bernard, R. M., Bures, E. M., Borokhovski, E., \&Tamim, R. M. (2012). The next generation of distance education. In L. Moller \&J . B. Huett (Eds.), The next generation of distance education: Unconstrained learning (pp. 49-69). Boston, MA: Springer US. doi:10.1007/ 978-1-4614-1785-9

Allen, M., Bourhis, J ., \& Burrell, N. (2010). Comparing student satisfaction with distance education to traditional classrooms in higher education : A metaanalysis. American J ournal of Distance Education (May 2013), 37- 41.

Allen, I., \& Seaman, J . (2013). Changing course: Ten years of tracking online education in the United States. Newburyport, MA: Sloan Consortium.

Anderson, C., Day, K., \& McLaughlin, P. (2008). Student perspectives on the dissertation process in a master's degree concerned with professional practice. Studies in Continuing Education, 30(1), 33- 49. doi:10.1080/01580370701841531

Arambewela, R., \& Hall, J . (2009). An empirical model of international student satisfaction. Asia Pacific J ournal of Marketing, 21(4), 555- 569. doi:10.1108/ 13555850910997599

Aspland, T., Edwards, H., O'Leary, J ., \& Ryan, Y. (1999). Tracking new directions in the evaluation of postgraduate supervision. Innovative Higher Education, 24(2), 127- 147.

Batalla-Busquets, J ., \& Pacheco-Bernal, C. (2013). On-the-job e-learning: Workers' attitudes and perceptions. The International Review of Research in Open and Distance Learning, 14(1), 40-64. Retrieved from http:// www.irrodl.org/ index.php/ irrodl/article/ view/ 1304/ 2417

Bennett, S., Bishop, A., Dalgarno, B., Waycott, J ., \& Kennedy, G. (2012). Implementing Web 2.0 technologies in higher education: A collective case study. Computers \& Education, 59(2), 524- 534. doi:10.1016/j.compedu.2011.12.022

Bolliger, D., \& Halupa, C. (2012). Student perceptions of satisfaction and anxiety in an online doctoral program. Distance Education, (May 2013), 37- 41. Retrieved from http:// www.tandfonline.com/doi/abs/10.1080/01587919.2012.667961

Buttery, E., \& Ruchter, E. (2005). An overview of the elements that influence efficiency in postgraduate supervisory practice arrangements. International J ournal of Educational Management, 19(1), 7- 26.

Carroll, C., Booth, A., \& Papaioannou, D. (2011). Experiences of e-learning and its delivery among learners who work: A systematic review. In R. Poell \& M. 
Woerkom (Eds.), Supporting workplace learning (pp. 47- 67). Springer Science \&Business Media. doi:10.1007/978-90-481-9109-3_4

Chen, P.-S. D., Lambert, A. D., \& Guidry, K. R. (2010). Engaging online learners: The impact of Web-based learning technology on college student engagement. Computers \& Education, 54(4), 1222- 1232. doi:10.1016/j.compedu.2009.11.008

Childs, S., Blenkinsopp, E., Hall, A., \&Walton, G. (2005). Effective e-learning for health professionals students - barriers and their solutions. A systematic review of the literature - findings from the HeXL project. Health Information and Libraries J ournal, 22(S2), 20- 32.

Collis, B., \&Wende van der, M. (2002). Models of technology and change in higher education: An international comparative survey on the current and future use of ICT in higher education. Enschede: CHEPS.

Cook, D., Levinson, A., \& Garside, S. (2008). Internet-based learning in the health professions: A meta-analysis. J ournal of the American Medical Association, 300(10), 1181- 1196.

Coughlan, S. (2013, February 27). Willetts urges UK universities to put courses online. BBC News. Retrieved from http:// www.bbc.co.uk/news/ education-21603703

De Kleijn, R. A. M., Mainhard, M. T., Meijer, P. C., Pilot, A., \& Brekelmans, M. (2012). Master's thesis supervision: Relations between perceptions of the supervisorstudent relationship, final grade, perceived supervisor contribution to learning and student satisfaction. Studies in Higher Education, 37(8), 925- 939. doi:10.1080/03075079.2011.556717

Driscoll, A., Jicha, K., Hunt, a. N., Tichavsky, L., \&Thompson, G. (2012). Can online courses deliver in-class results?: A comparison of student performance and satisfaction in an online versus a face-to-face introductory sociology course. Teaching Sociology, 40(4), 312- 331. doi:10.1177/0092055X12446624

Gemmell, I., Harrison, R., Clegg, J ., \& Reed, K. (in press). Internationalisation in post graduate education: Student views on the impact of learning alongside students from other countries on an online distance learning master of public health programme. Innovations in Education and Teaching International.

Halsne, A., \& Gatta, L. (2002). Online vs. traditionally-delivered instruction: A descriptive study of learner characteristics in a community college setting. Online J ournal of Distance Learning Administration2, 5(1).

HEFCE. (2012). The National Student Survey. Retrieved May 28, 2013, from http:// www.hefce.ac.uk/ whatwedo/lt/publicinfo/nationalstudentsurvey/ 
J ISC. (2007). e-Learning Pedagogy Programme. Retrieved from http:// www.jisc.ac.uk/ whatwedo/programmes/elearningpedagogy.aspx

Ke, F., \& Kwak, D. (2013). Constructs of student-centered online learning on learning satisfaction of a diverse online student body: A structural equation modeling approach. J ournal of Educational Computing Research, 48(1), 97- 122. doi:10.2190/ EC.48.1.e

Kuo, Y., Walker, A., Belland, B., \& Schroder, K. (2013). A predictive study of student satisfaction in online education programs. The International Review of Research in Open and Distance Learning, 14(1), 16- 39.

Levy, Y. (2007). Comparing dropouts and persistence in e-learning courses. Computers \&Education, 48(2), 185-204. doi:10.1016/j.compedu.2004.12.004

Maykut, P., \& Morehouse, R. (1994). Qualitative data analysis: Using the constant comparative technique. In Beginning qualitative research: A philosophical and practical guide (pp. 126- 50). London: Falmer Press.

McCallin, A., \&Nayar, S. (2012). Postgraduate research supervision: A critical review of current practice. Teaching in Higher Education, 17(1), 63- 74.

Means, B., Toyama, Y., Murphy, R., Bakia, M., \&J ones, K. (2009). Evaluation of evidence-based practices in online learning. (M. Barbara, T. Yukie, M. Robert, B. Marianne, \&J. Karla, Eds.) Structure, 15(20), 94. Retrieved from http://newrepo.alt.ac.uk/629/

Meeus *, W., Van Looy, L., \& Libotton, A. (2004). The bachelor's thesis in teacher education. European J ournal of Teacher Education, 27(3), 299- 321. doi:10.1080/0261976042000290813

Naidoo, V. (2005). From policy to implementation. In A. Hope \& P. Guiton (Eds.), Strategies for open and sustainable distance learning: World review of distance education and open learning (1st ed.). London: Routledge.

Pilcher, N. (2011). The UK postgraduate master's dissertation: An "elusive chameleon"? Teaching in Higher Education, 16(1), 29- 40. doi:10.1080/13562517.2011.530752

Quan-Baffour, K., \&Vambe, M. (2008). Critical issues in the supervision of postgraduate dissertations in distance education environments. Open Education, 4(1), Section One.

Sahin, I., \& Shelley, M. (2008). Considering students' perceptions: The distance education student satisfaction model. Educational Technology \& Society, 11(3), 216- 223 
Sanders, R. (2006). The "Imponderable Bloom": Reconsidering the role of technology in education. InnovateJ ournal of Online Education, 2(6).

Sharpe, R., \& Benfield, G. (2005). J ISC research elearning experience \& pedagogy. J ISC.

The Sloan Consortium. (2013). Sloan-C Quality Framework. The 5 Pillars.

Thomas, J . (2013). Exploring the use of asynchronous online discussion in health care education: a literature review. Computers \& Education.

doi:10.1016/j.compedu.2013.07.005

Weller, M. (2011). The digital scholar. Bloomsbury Publishing PLC. doi:10.5040/9781849666275

Wickersham, L., \& McGee, P. (2008). Perceptions of satisfaction and deeper learning in an online course. Quarterly Review of Distance Education, 9(1), 73- 83.

Zhang, W. Y., Perris, K., \&Yeung, L. (2005). Online tutorial support in open and distance learning: Students' perceptions. British J ournal of Educational Technology, 36(5), 789- 804.

\section{Athabasca University $\mathbf{a}$}

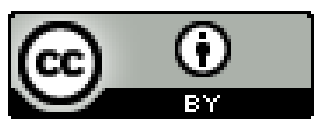

